\title{
Online Video Effect as a Learning Media in Improving Speaking Ability English Class X Students of Hang Tuah 4 High School Surabaya Study Year 2017/2018
}

\author{
Author \\ Sulistiyani, Nur Hidayat, Nuurus Sa'aadah \\ Correspondence \\ STKIP Bina Insan Mandiri Surabaya \\ sulistiyani@stkipbim.ac.id, nurhidayat@stkipbim.ac.id, nuurussaadah@stkipbim.ac.id
}

doi : 10.30587/kontribusia.v1i1.249

URL:http://dx.doi.org/10.30587/kontribusia.v1i1.249

\begin{abstract}
This research is motivated by the role of language that is very important in the development of science and technology, especially English which is one of the foreign languages that are widely used in every aspect of life such as science, education, culture, business, and entertainment. The author looks at the reality of the lack of mastery of English in the educational environment, especially in the ability to speak. This study aims to describe changes in behaviour after learning English using online video learning media. The theoretical benefit of this research is for the development of science and as a provision for teachers so that it can overcome the problems that occur to students in order to improve the quality of education better. Practical benefits of this research are expected to provide input for English teachers in choosing media as an alternative to improve the quality of learning English and can provide input to teachers in the use of online learning video media for learning English (the ability to speak). The method used in this study is a research method of classroom action with two cycles carried out on the teacher discuss a UK and students of class X SMA Hang Tuah 4 Surabaya. Each cycle consists of stages of planning, action, observation and reflection. Data collection is carried out by testing and non-test. Data analysis is carried out with quantitative and qualitative techniques. Quantitative data analysis is obtained by calculating the overall student value and recapping the test scores, then calculating the average value obtained. The expected results of this study can be concluded that learning by using online video learning media can improve students' speaking ability and can change student behaviour towards positive.
\end{abstract}

Keywords: Speaking Ability, Online Video as Learning Media

Received: 10 April 2018. Accepted: 25 June 2018

\section{INTRODUCTION}

The educational curriculum travels to a better purpose than educators or students. In the implementation of the 2013 curriculum, KTSP experienced several problems, one of which was about the contents of English books which were considered to have experienced a decline in quality (Hidayat, 2017). However, with the process of the 2013 curriculum, the government also revised the curriculum book to improve the quality of the book. Actions from the government are deemed necessary to be balanced with the productivity of educators in making learning media so that the material contained in the book can be conveyed more interestingly.

According to Sadiman et al. (1993), learning media is everything that can be used to channel messages from the sender to the recipient so that it can stimulate students' thoughts, feelings, attention, and interests in such a way that the learning process occurs. Effective. The media becomes a tool to improve the effectiveness of learning and student interest in the learning process in the classroom (Hidayat, 2018).

Current technological developments also affect the shape and transformation of conventional media into electronic media. The use of the internet that has mushroomed in the world of education has become a new alternative in the productivity of internet-based media. Internet media that can be applied to learning one of them is online video. Online videos here can be sourced from various websites including youtube, TED talk, British Council and others. Riswandi (2016) 
explained that the use of YouTube online videos could improve students' speaking skills. The same thing was also conveyed by Erlangga (2016) who stated that one of the media that can be used in improving students' speaking skills is by using videos.

However, in the use of online video-based media need to consider the suitability, how to use media and facilities with real subjects that are relevant to the skill. The ability of educators \& students is also an essential requirement in the application of online video-based media in learning one of which is in improving speaking skills.

SURABAYA HANG TUAH 4 SMA owns internet facilities. However, there are problems in classroom learning, especially in English lessons in class $X$ that need to be addressed. The speaking skills of class $X$ students still do not meet the KKM, so it needs to be improved. For this reason, the author tries to do research using online videos as a learning medium in improving the ability to speak English in class X of HANG TUAH 4 SMA SURABAYA in the academic year 2017/2018.

The problem studied in this study is whether online video as a learning medium has the influence and effectiveness of online video as a learning medium to improve English speaking skills in class X Hang Tuah High School 4 Surabaya Academic Year 2017-2018?

\section{Research purposes}

The aim to be achieved in this study is to improve the speaking skills of class X Hang Tuah High School 4 Surabaya 2017/2018 Academic Year with online video media.

\section{Method}

This study uses classroom action research procedures. To realise these goals, the classroom action research was carried out in the form of a recapitulation study process consisting of four stages: planning, action, observation, and reflection.

\section{Research subject}

The subjects of this study were 46 students of class X.IIS I at SMA Hang Tuah 4 Surabaya in the academic year 2017/2018.

\section{Research Procedure in Cycle I}

\section{a. Planning}

At this stage, researchers plan everything that is needed in implementing CAR starting from planning actions, meeting in implementing actions, preparing instruments at the time the action is given and analysing the results of actions.

\section{b. Action}

In this step, the instructor provides an online video action that utilises internet facilities. Videos are taken from several sources including; youtube, TED talk and British council (learning English teens). Giving action is carried out when learning takes place at the core time. Students are invited to see English conversations on online videos with English subtitles. Then the instructor asks students to practice the conversation with their friends. After practising it, students are invited to discuss the video. The action is carried out in 2 meetings.

\section{c. Observation}

At this stage, the researcher acts as an observer. Researchers observe the condition of students in the classroom when the teacher applies to learn using online video media.

\section{d. Reflection}

Reflection is reviewing, seeing, and considering the results or effects of actions. Reflection is carried out after actions and observations have been carried out. From the results of these observations, the researcher can see whether the student has experienced an increase or not. If the results indicate that the increase is considered not optimal, then the cycle II must be implemented.

\section{Research Procedure in Cycle II}

The classroom action research process in cycle II can be described as follows.

\section{a. Planning}

Planning in cycle II is based on the findings of the first cycle results that have been evaluated and experienced improvements.

\section{b. Action}

The actions carried out by the researcher in cycle II are based on the findings of the results of the first cycle which are modified by considering the results of the cycle I.

\section{c. Observation}


Observations in cycle II are also the same as a cycle I which includes student observation, teacher observation and class observation.

\section{d. Reflection}

Reflection on the second cycle is used to reflect the results of student learning cycle I to determine the progress that has been achieved during the learning process, and to find weaknesses that still appear in classroom learning.

\section{Research Instruments}

The form of this research instrument includes test instruments and notes instruments.

For processing the value is calculated by the following formula.

$$
\mathrm{N}=\frac{(\mathrm{A}+\mathrm{B})}{2}
$$

Information:

$\mathrm{N}=$ Value

$\mathrm{A}=$ Answering questions from online video display as a learning medium

$\mathrm{B}=$ Retelling the content of online video media as a learning

(Arikunto, 2002)

The non-instruments used in the form of observations, journals, interviews, and documentation.

\section{Data collection technique}

Data collection was carried out with observation techniques, journals, interviews, and test devices to obtain an overview of the results of speaking learning by using online video as a learning medium.

\section{Data analysis technique}

Data analysis techniques in this study are qualitative techniques and quantitative techniques. Qualitative techniques are used to analyze qualitative data. Data analysis is obtained from non-test data, namely observation data, journals, interviews, and photo documentation.

Quantitative data is obtained by calculating the overall value of students and recapping test scores. Then calculate the average value obtained. Here is the percentage value formula.

$\mathrm{NP}=\underline{\mathrm{R}} \times 100 \%$
$J S$

Information:

$\mathrm{NP}=$ Value in percent

$\mathrm{R}=$ Score achieved by students

JS $=$ The total number of students (Arikunto, 2002)

The results of the calculation of student scores from each of these tests are then compared between the results of the first cycle test and the second cycle test results. These results will provide an overview of the percentage of improvement in speaking ability using online video as a learning medium

\section{Result}

This study is a classroom action research with online video as a learning medium in improving the ability to speak in class X SMA Hang Tuah 4 Surabaya Academic Year 2017/2018

The results of the first cycle of the action test and the second cycle can speak after getting online video learning as a learning medium. Whereas the results of non-contest are student activeness during the learning that is obtained through observation activities, journals and interviews.

\section{Initial conditions}

The initial condition is the condition of students before learning by using online video as a learning medium. To find out the students' speaking ability before a class action is in the form of learning with online video as a learning medium, an initial test and observation of student activity during learning take place.

\section{a. Test Results}

In order to find out the students' speaking skills before getting online video teaching as a learning medium, an initial test is conducted. After the teacher assesses the results of written tests and oral tests of speaking ability, the results are obtained as stated in the following table:

\begin{tabular}{cccccc}
\multicolumn{6}{c}{ Table 1. Speaking Ability Test Results } \\
\hline No. & Category & Value & Freq & \% & Avg \\
\hline 1. & Very good & $8,5-10,0$ & 0 & $0.00 \%$ & \\
2. & Good & $7,0-8,4$ & 1 & $2.17 \%$ & 5,4 \\
3. & Enough & $5,5-6,9$ & 23 & $50.00 \%$ & \\
4. & Less & $<5,5$ & 22 & $47.83 \%$ & \\
\hline \multicolumn{7}{r}{ amount } & $\mathbf{4 6}$ & $\mathbf{1 0 0 \%}$ & \\
\hline \multicolumn{7}{r}{}
\end{tabular}

More clearly the ability to speak students before getting action can be seen in the following graph. 


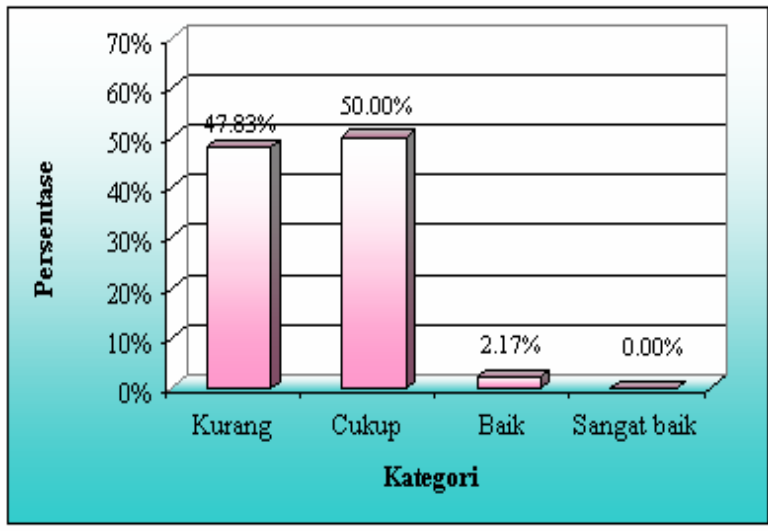

Figure 1. Graph of Pre-Action Students' Speaking

Based on Figure 2 above it can be seen that before getting the action of most students that is $47.83 \%$ have the ability to speak in the less category and $50.00 \%$ in the sufficient category while students who can speak in a suitable category only 2.17 . The average pre-action value has only reached 5.4 and is categorised as lacking. The value obtained from each student can be seen in the following graph.

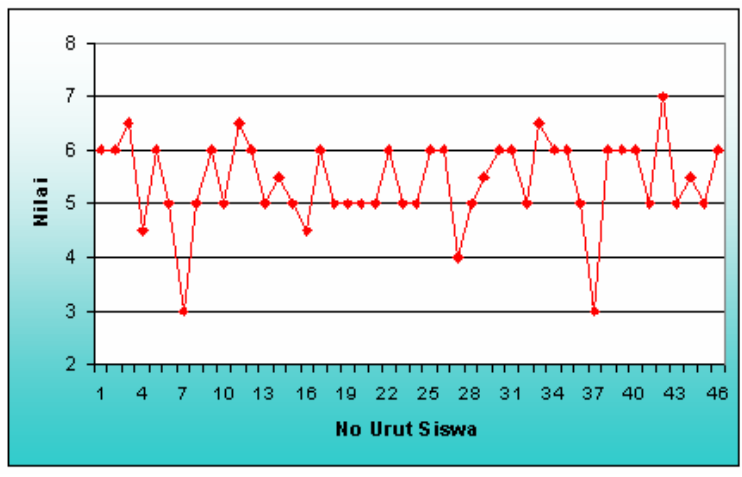

Figure 3. Pre-action value search graph

Figure 3 above it can be seen that most of the students got grades between 5-6, which were as many as 37 students. Moreover, five students received scores of less than 5 and four students scored above 6 .

\section{b. Nontes results}

The non-content activity carried out in this preaction stage is in the form of classroom observations when learning activities take place.

\section{c. Action Reflections}

The low ability of students to speak English before a class action is conducted shows that teaching activities conducted by the teacher have not fully been able to guide all students to master all the material both grammar, pronunciation, and vocabulary.

\section{Cycle I Research Results}

In the results of the research cycle, I will discuss the results of tests and non-test results after learning with online video as a learning medium. The test results are the value of the verbal ability test and non-test results including observation data, student and teacher journals and interviews with students.

\section{a. Test Results}

After the test was carried out at the end of the learning cycle, I obtained the results as listed in the table below.

Table 2. Speaking Ability Test Results Cycle 1

\begin{tabular}{clcccc}
\hline No. & Category & Value & Freq & \% & Avg \\
\hline 1. & Very good & $8,5-10,0$ & 0 & $0.00 \%$ & \\
2. & Good & $7,0-8,4$ & 19 & $41.30 \%$ & 6,3 \\
3. & Enough & $5,5-6,9$ & 22 & $47.83 \%$ & \\
4. & Less & $<5,5$ & 5 & $10.87 \%$ & \\
\hline \multicolumn{7}{r}{ Jumlah } & & $\mathbf{4 6}$ & $\mathbf{1 0 0 \%}$ & \\
\hline
\end{tabular}

More clearly the ability to speak students after achieving action in my cycle can be seen in this graph.

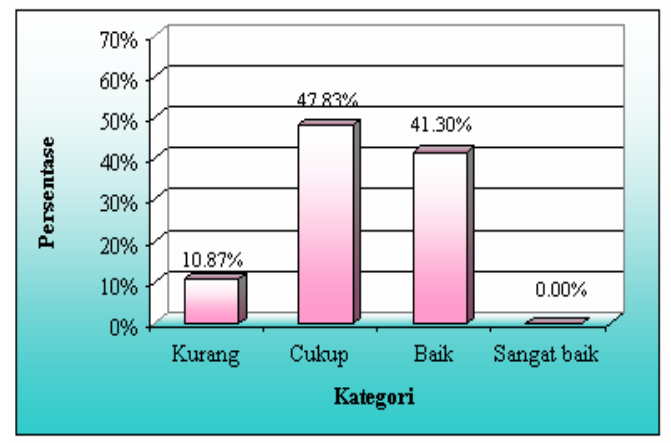

Figure 3. Graph of Students' Speech Ability Cycle I

Based on Figure 4 above shows that the ability of students in speaking at the end of the learning cycle I began to increase. In pre-action learning activities there is only one student or $2.17 \%$ who get good grades, at the end of the learning cycle I students who get good grades increase to 19 students or $41.30 \%$. Thus, students who received good grades from pre-action activities to cycle I experienced an increase of $39.3 \%$. Students who received enough scores in pre-action activities amounted to 23 students or $50 \%$, at the end of the learning cycle I students who received enough scores were reduced to 22 students or $47.83 \%$. Thus, students who get enough category scores from pre-action to cycle I decreased by $2.17 \%$. 
Students who received fewer scores in preaction activities amounted to 22 students or $47.83 \%$, at the end of the learning cycle I the number of students who received fewer grades experienced a decrease to 5 students or $10.87 \%$. Thus, students who received fewer category scores decreased by $36.96 \%$. Overall, the average score of students' speaking ability at the end of the first cycle of learning increased from 5.4 to 6.3. The value of each student can be seen in the following graph.

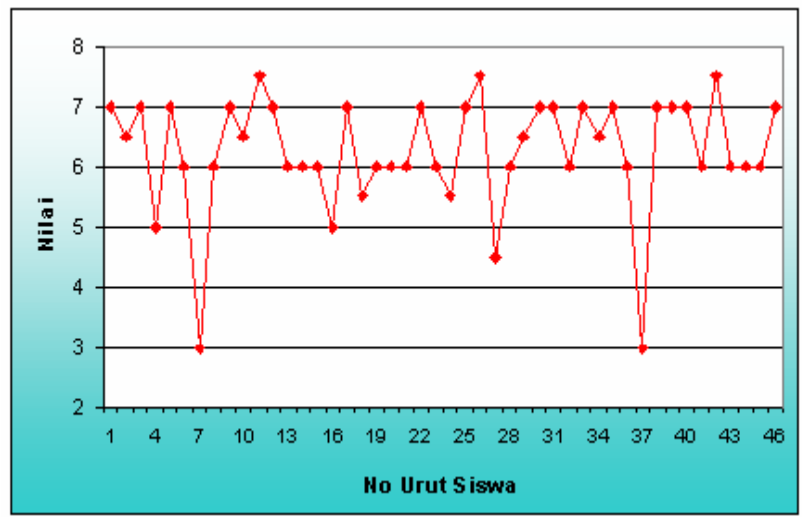

Figure 4. Graph of Cycle I Value Displacement

Figure 5 above it can be seen that most students get grades between 6-7 as many as 36 students. Moreover, three students get grades above 7 , and 7 students get a score below 6 .

\section{Nontes results}

\section{Student Observation}

Observation activities carried out in cycle I showed that the activeness of students in listening to the teacher's explanation in the first cycle of learning showed an increase to be high (78\%). Judging from the activeness of students when learning showed an increase and was included in the category enough $(77 \%)$. This is due to the teaching that uses online video as a medium of learning; students look interested in imitating the conversations in online video, students begin to speak quite fluently when answering questions from the teacher or when asked to retell the conversations in the video online as a learning medium.

\section{Teacher observation}

Based on the observations of the learning activities conducted by the teacher, it was seen that the teacher's ability to plan to learn in cycle I was good $(91 \%)$, the teacher's ability to carry out teaching programs was also good (89\%), and the teacher's ability to carry out personal relationships with students was also seen as good (89\%).

\section{Student Journal}

From the student journals in the first cycle, it was known that most students, $83 \%$ of students stated the learning they had followed was good because speaking learning using online video as a learning medium made learning not boring, material that was packaged in online video as learning media was seen by students as fun (75\%) and student impression, with online video as a learning medium, the method becomes easy to understand (85\%). Difficulties experienced by students in learning cycle I am still the same as what happened in pre-action, namely the difficulty in following the learning because they have not fluent in English, this is expressed by $40 \%$ of students.

\section{Teacher Journal}

Based on the journals the teacher made on the learning process that students followed showed that the use of learning aids in the form of online video as a learning medium turned out to be very helpful in increasing student activity in learning.

\section{Interview}

The results of the interviews showed that $89.13 \%$ of students were very enthusiastic and enthusiastic about participating in online videobased learning. While $10.87 \%$ of students were enthusiastic but experienced difficulties, especially in practicing conversations in English. Besides that, they are also not familiar with the method applied by the teacher.

\section{Reflection of Cycle I}

Through online video learning as a learning medium in cycle I, it seems that the learning done by the teacher starts to be much liked by students so that their ability to speak becomes increased. However, the increase was deemed not optimal, so it was necessary to act in cycle II.

\section{Cycle II Research Results}

In the results of the second cycle research results will be discussed the results of the test and nontes sisklus II after learning with online video as a learning medium.

a. Test Results

The test results in question are the results of tests about the students' ability to speak. After the 
second cycle test has been carried out, the test results as listed below are obtained.

Table 6. Student Cycle II Speaking Ability Test

Results

\begin{tabular}{|c|c|c|c|c|c|}
\hline No. & Category & Value & Freq & $\%$ & Avg \\
\hline 1. & Very good & $8,5-10,0$ & 10 & $21.74 \%$ & \multirow{4}{*}{7,6} \\
\hline 2. & Good & $7,0-8,4$ & 29 & $63.04 \%$ & \\
\hline 3. & Enough & $5,5-6,9$ & 5 & $10.87 \%$ & \\
\hline 4. & Less & $<5,5$ & 2 & $4.35 \%$ & \\
\hline \multicolumn{3}{|c|}{ Jumlah } & 46 & $100 \%$ & \\
\hline
\end{tabular}

More clearly the ability of students to speak after getting action in cycle II can be seen in the following graph.

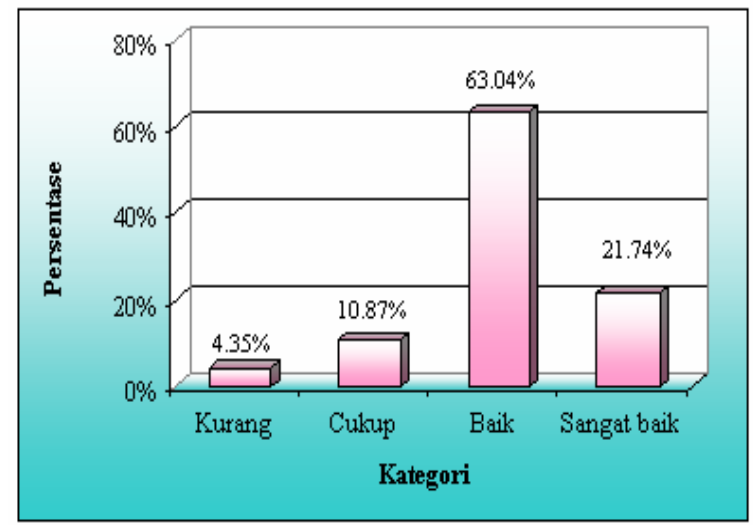

Figure 5. Graph of Speaking Ability Cycle II

Based on Figure 6 above shows that the ability of students in speaking at the end of the learning cycle II has increased. In the first cycle of learning activities, there are no students who get excellent grades, in cycle II there are students who get outstanding grades of 10 students or $21.74 \%$. Thus, the percentage of students who obtained excellent category scores increased by $21.74 \%$. Students who obtained good category scores in the first cycle of learning activities amounted to 19 students or $41.30 \%$, at the end of learning cycle II students who received good category scores amounted to 29 students or $63.04 \%$.

Thus, the percentage of students who received good grades experienced an increase of $21.74 \%$. Students who obtained enough category scores in the first cycle learning activities were 22 students or $47.83 \%$, at the end of the learning cycle II students who obtained enough category scores decreased to 5 or $10.87 \%$. Thus, the percentage of students who received enough category scores decreased by $36.96 \%$. Students who received fewer category scores in the first cycle learning activities were 5 students or $10.87 \%$, at the end of the cycle learning students who received fewer category scores were only 2 students or $4.35 \%$. Thus, the percentage of students who received fewer grades decreased by $6.52 \%$. If viewed from the average value of students' speaking ability at the end of the learning cycle II this has reached 7.6.

From these results, it can be explained that online video learning as a second cycle learning media has been able to improve students' speaking ability optimally because it has been able to deliver students to reach the minimum limit of learning outcomes that is 7.0. The value obtained from each student can be seen in the following graph.

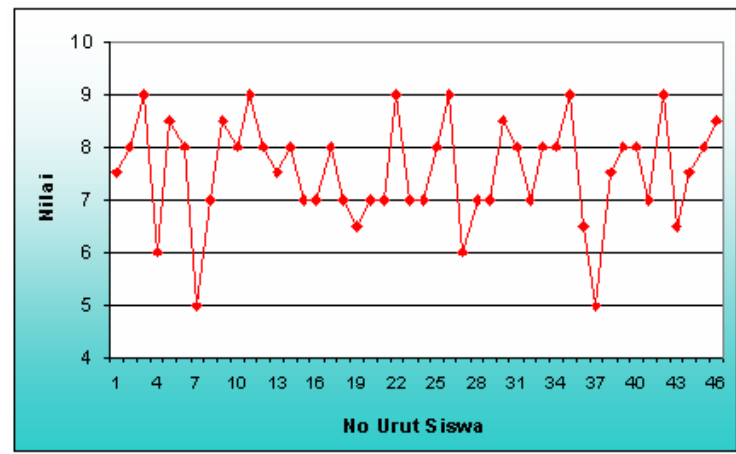

Figure 6. Cycle II Cycle Illustration

Figure 7 above it can be seen that most students get a score of 7-9, which is 39 students and only 7 students who still score less than 7 .

\section{Nontes results}

1. Student

The results of observation activities show that in speaking cycle II learning activities, student activity is increasing $(92 \%)$.

\section{Teacher}

Based on observations on learning activities conducted by the teacher, it appears that the teacher's ability to plan to learn in cycle II is also good (96\%), the ability of teachers to carry out teaching programs has also been good $(100 \%)$ and the ability of teachers in carrying out personal relationships with students as well looks good (96\%).

\section{Journal}

The journal used in the second cycle is still the same as the first cycle, namely about students' impressions about the way teaching is used, students' responses to online video use as a medium for speaking learning, students' impression of the spoken material that has been taught, difficulties with the material taught and 
students' suggestions for upcoming teaching and learning activities.

\section{Interview}

The results of interviews with students in cycle II showed that students seemed to be familiar with the methods used and students liked the way of teaching used by teachers, especially related to the use of online video as a learning medium.

\section{Cycle II Reflection}

Students' ability to speak based on test results at the end of cycle II learning shows a significant increase and has exceeded the minimum standard limit of 7.6.

\section{Discussion}

In the pre-action speaking learning activities and cycle I it seems that the students' ability in speaking has not met the specified target (6.5). The average value of students' ability to speak in the new action reaches 5.4, and the first cycle reaches 6.3 .

In the second cycle, learning activities continue to use online video as a learning medium, but with a more straightforward material selection regarding conversation, it can optimise the ability to speak. This can be seen from the increase in the average grade of the cycle II which reached 7.6 and exceeded the minimum limit of the standard values that students had to achieve, namely 7.5. When compared with the average value of cycle I, which is 6.3 to 7.6 in cycle II, the average value of students has increased by 1.3 or $20.6 \%$. More detailed, improving students' ability to speak after getting to teach with online video as a learning medium can be seen in the improvement of student learning outcomes in the following picture.

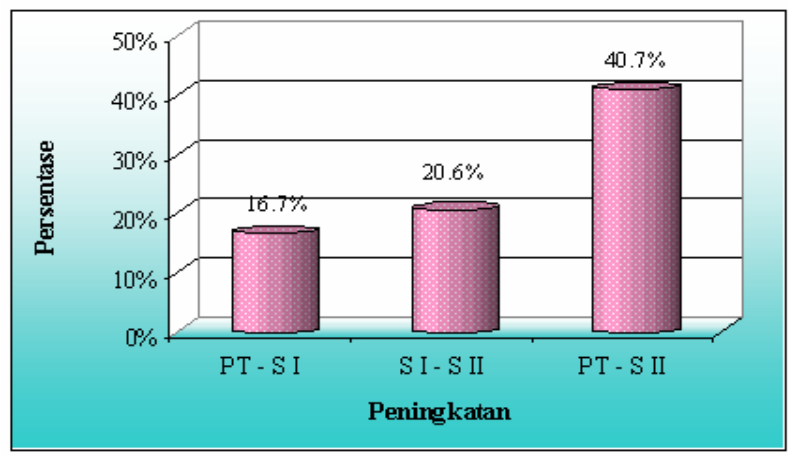

Figure 7. Increasing Students' Speaking Ability
The data in figure 8 above is a recapitulation of the improvement of pre-action speaking skills, the cycle I and cycle II. From the figure, it seems that each action shows an increase in students' speaking ability. In the action cycle, I was able to improve students 'speaking ability by $16.7 \%$ while in cycle II they were able to improve students' abilities by $20.6 \%$ from the previous cycle.

In general, the improvement of students 'speaking ability from classroom action in the form of online video use as a medium in speaking learning is carried out as much as two cycles able to improve students' speaking ability by $40.7 \%$ and has been able to deliver students to the minimum completeness of learning outcomes because of the learning outcomes achieved by students amounting to 7.6 and greater than 7.0. These findings are in line with the opinions expressed by Riswandi (2016) and Erlangga (2016) who have proven the use of video media to improve students' speaking skills. The use of video media is also able to make speaking learning in the classroom more effective (Manurung, 2014; Pradana 2016).

Based on the description above it seems that the use of online video as a learning medium is beneficial to improve the speaking skills of class X.A high school students in Hang Tuah 4 Surabaya 2017/2018 Academic Year.

\section{Conclusion}

Based on the results of the study it can be concluded that through the application of learning models that use online video as a learning medium, can improve students' speaking skills. This is evident from the increase in the average ability of students from 5.4 at the time of pre-action to 6.3 in cycle I and 7.6 in cycle II.

The improvement of students 'speaking skills is due to an increase in students' behaviour when learning from pre-action to cycle I actions and cycle II actions. In the beginning, the students' interest in learning English was still low, the difficulty of students in learning English was quite high, and the courage of students to speak well with friends or with teachers using English was also low. Students dare to ask questions, answer questions or provide comments on the material that is being also conveyed the teacher increases. 


\section{Suggestion}

Based on the conclusions above, it is suggested:

1. As consideration for the English teacher, learning should be conducted on the subject of speaking by using online video as a learning medium, so that learning becomes more optimal.

2. Further research needs to be carried out by taking another subject so that more convincing results can be obtained about the effectiveness of online video as a learning medium for learning English.

\section{References}

Arikunto, Suharsimi. 2002. Prosedur Penelitian Suatu Pendekatan Praktek.Yogyakarta: Rineka Cipta.

Arikunto, Suharsimi. 2002. Dasar-dasar Evaluasi Pendidikan. Jakarta: BumiAksara.

Erlangga, R. A. (2016). Enhancing Students ' Speaking Skills through "Kunci Inggris" Videos in Islamic Junior High School. Journal of Education and Practice, 7(36), 170-180.

Hidayat, N. (2017). Developing E-Reading Materials for Students of Grade Seven. Journal of English Educators Society, 3344.

Hidayat, N. (2018). Training Media Learning for Teachers of MI Citra Taman Siswa. Kontribusia, 55-57.

Manurung, K. (2014). The Implementation of Video Learning. English Language Teaching Society, 2(3), 1-14.

Pradana, S. A. (2016). The Use of Videocast in Improving the Speaking Ability Integrated in a Drama Class, 9(2), 409-428.

Riswandi, D. (2016). Use of YouTube-Based Videos to Improve Students' Speaking Skill Diki Riswandi. The 2nd International Conference on Teacher Training and Education Sebelas Maret University, 2(1), 298-306.

Sadiman, Arief S, dkk. 1996. Media Pendidikan: Pengertian, Pengembangan danPemanfaatannya. Jakarta: Raja Grafindo Persada. 